\title{
Investigation of the antifouling constituents from the brown alga Sargassum muticum (Yendo) Fensholt
}

\author{
Alexandra Bazes • Alla Silkina • Philippe Douzenel • \\ Fabienne Faÿ • Nelly Kervarec • Danièle Morin • \\ Jean-Pascal Berge $•$ Nathalie Bourgougnon
}

Received: 24 January 2008 /Revised and accepted: 11 September 2008 /Published online: 3 October 2008

(C) Springer Science + Business Media B.V. 2008

\begin{abstract}
One of the most promising alternatives to toxic heavy metal-based paints is offered by the development of antifouling coatings in which the active ingredients are compounds naturally occurring in marine organisms and operating as natural antisettlement agents. Sessile marine macroalgae are remarkably free from settlement by fouling organisms. They produce a wide variety of chemically
\end{abstract}

A. Bazes $\cdot$ A. Silkina $\cdot$ F. Faÿ $\cdot$ D. Morin $\cdot$ N. Bourgougnon

Laboratoire de Biotechnologie et Chimie Marines,

Centre de Recherche Saint Maudé,

Université Européenne de Bretagne, Université de Bretagne-Sud,

56321 Lorient Cedex, France

P. Douzenel

UFR de Sciences et Sciences de l'Ingénieur,

Département Sciences de la Vie et de la Matière,

Campus de Tohannic, Université Européenne de Bretagne,

Université de Bretagne-Sud,

CER Yves Coppens,

56017 Vannes Cedex, France

N. Kervarec

Laboratoire de Résonance Magnétique,

Université Européenne de Bretagne,

Université de Bretagne Occidentale,

6 avenue Victor le Gorgeu, CS93837,

29238 Brest Cedex 3, France

J.-P. Berge

Département Sciences \& Techniques Alimentaires Marines, IFREMER,

Rue de l'île d'Yeu, B.P. 21105, 44311 Nantes Cedex 03, France

Present address:

A. Bazes $(\square)$

Laboratoire de Microbiologie, Equipe Applications bioindustrielles, Université Catholique de Louvain-La-Neuve,

Croix du Sud 3, boite 6,

1348 Louvain la Neuve, Belgique

e-mail: alexbazes@yahoo.fr active metabolites in their surroundings, potentially as an aid to protect themselves against other settling organisms. In this study, a dichloromethane extract from the brown seaweed Sargassum muticum was tested in situ and, after 2 months of immersion, showed less fouling organisms on paints in which the extract was included, compared to paints containing only copper after 2 months of immersion. No barnacles or mussels have been observed on the test rack. Identification by NMR and GC/MS of the effective compound revealed the abundance of palmitic acid, a commonly found fatty acid. Pure palmitic acid showed antibacterial activity at $44 \mu \mathrm{g} \mathrm{mL}^{-1}$, and also inhibited the growth of the diatom Cylindrotheca closterium at low concentration $\left(\mathrm{EC}_{50}=45.5 \mu \mathrm{g} \mathrm{mL}^{-1}\right)$, and the germination of Ulva lactuca spores at $3 \mu \mathrm{g} \mathrm{mL}^{-1}$. No cytotoxicity was highlighted, which is promising in the aim of the development of an environmentally friendly antifouling paint.

Keywords Antifouling · Brown algae .

Dichloromethane extract - Dioctyl phthalate - Palmitic acid .

Sargassum muticum

\section{Introduction}

Engineered structures such as ships and marine platforms, as well as offshore rigs and jetties, are under constant attack from the marine environment. These structures need to be protected from the influences of the key elements of the marine environment such as saltwater, biological attack and temperature fluctuations. The settlement and accumulation of marine organisms on an inanimate substrate can cause large penalties to engineered structures. In heat exchangers, biofouling can clog systems, and on ship hulls it can 
increase the hydrodynamic drag, lower the manoeuvrability of the vessel and increase the fuel consumption. This leads to increased costs within the shipping industry through the increased use of manpower, fuel, material and dry docking time (Abarzua and Jakubowski 1995; Lambert et al. 2006; Chambers et al. 2006).

The process of biological fouling is often grouped in the literature into key growth stages, which include an initial accumulation of adsorbed organics, the settlement and growth of pioneering bacteria creating a biofilm matrix and the subsequent succession of micro and macrofoulers (Wahl 1989; Abarzua and Jakubowski 1995; Yebra et al. 2004). Methods for inhibiting both organic and inorganic growth on wetted substrates are varied, but most antifouling systems take the form of protective coatings. Unfortunately, operational profiles vary; hence the application of one universal coating to ship hulls is unlikely and specific coatings designed for the particular needs of certain exposure and operational profiles may need to be targeted individually. Heavy metals and booster biocides such as Irgarol 1051 and Diuron, are not environmentally acceptable alternatives due to increased concerns over their toxicity, but do offer cost benefits (Chambers et al. 2006). The International Maritime Organisation (IMO) legislation and the increased legislation of local and regional pesticide control authorities are the largest driving forces for the design and implementation of non-toxic antifouling coatings (Chambers et al. 2006).

The biomimetics approach implies the use of the natural world as a model on which to base an engineering development. Marine organisms have been shown to use both physical and chemical methods to protect themselves from biofouling (Bakus et al. 1986; Davis et al. 1989; Wahl 1989; Steinberg et al. 1998; Fusetani 2004; Bazes et al. 2006).

The introduced macroalga Sargassum muticum (Heterokonta, Fucales) is found along the coasts of South Brittany (Critchley et al. 1990; Plouguerne et al. 2006). Similar to many other macroalgae, S. muticum may accumulate quantities of secondary metabolites (Hay and Fenical 1988; Steinberg 1992; Hay 1996) generally assumed to be a chemical defence against grazers and bacterial colonisation (Sieburth and Conover 1965; Hay and Fenical 1988; Harlin 1996; Plouguerne et al. 2006). The chemical composition of Sargassum has been studied extensively, and phlorotannins (Kubo et al. 1992), phlorethols (Banaimoon 1992), sterols (Harvey and Kennicutt 1992) and dicotylpthalate (Sastry and Rao 1995) have been isolated. Various extracts from this alga have shown biological activities, including bactericidal and fungicidal (Sastry and Rao 1994, 1995; Hellio et al. 2001; Bazes 2006).
In this paper, we report on the isolation and identification of a potential natural antifouling compound from a dichloromethane extract of $S$. muticum.

\section{Materials and methods}

The brown alga Sargassum muticum (Yendo) Fensholt was harvested in Locmariaquer $\left(47.55^{\circ} \mathrm{N}, 2.90^{\circ} \mathrm{W}\right.$, Brittany, France) in March 2004. After collection, the material was rinsed in sterile seawater and 5\% ethanol in order to remove any associated microflora. Algae were then dried at room temperature under shade, and stored in the dark before use.

Extraction was performed as previously described by Hellio et al. (2001). The dried algae were suspended by stirring in ethanol $(2,000 \mathrm{~g} / 12 \mathrm{~L})$. After decantation, the resultant pellet was re-extracted five times in the same way. The alcoholic extracts were combined and evaporated under vacuum at low temperature $\left(35^{\circ} \mathrm{C}\right)$. Distilled water $(4 \mathrm{~L})$ was then added and partitioned with dichloromethane $(4 \times 4 \mathrm{~L})$. The organic phases were collected, left dry in presence of $\mathrm{Na}_{2} \mathrm{SO}_{4}$ for $24 \mathrm{~h}$, filtered and concentrated under vacuum at low temperature (dichloromethane extract). The resulting dichloromethane extract (A) was stored at $4^{\circ} \mathrm{C}$ before use. The extraction yield was $0.85 \%$.

Biocides commonly used in commercial antifouling paints were also evaluated on marine bacteria, microalgae and macroalgae spores. Diuron, Irgarol 1051, Tolylfluanid and Dichlofluanid were provided by Nautix, France.

Binders and paints

The binder used was purchased from ZENECA. It is a mixture of an acrylic copolymer (polybutylmethacrylate-copolymethylmethacrylate) with rosin. The relative amount of rosin influences the erosion properties of the final paints. Paints were formulated with this polymer (cf. Table 1). All the ingredients were dispersed under vigorous agitation $(2,000 \mathrm{~g})$ for $1 \mathrm{~h}$. Then the paints were filtered through a $100-\mu \mathrm{m}$ sieve.
Table 1 Composition of paints (wt.\%)

\begin{tabular}{ll}
\hline Composition & Paint \\
\hline Polymer & 16.3 \\
Solvent (xylene) & 40 \\
Extract & 9.5 \\
Copper & 10 \\
Fillers & 18.7 \\
Additives & 5.5 \\
\hline
\end{tabular}


Immersion and test procedures

Test panels were coated by using an automatic film applicator (Sheen 1137). The wet films were $200 \mu \mathrm{m}$ thick. After drying, plates were immersed in the harbour of Lorient (Britanny, France) for 2 months, July and August, when the fouling pressure is the highest. The plates were immersed under the surface, where most of the fouling organisms live.

Purification of the active extract

For each step of purification, the different fractions were tested against three agents of microfouling. The most active fraction was retained for a further purification step.

$1.5 \mathrm{~g}$ of the dichloromethane extract (A) was added to a Solid Phase Extraction (SPE) column (Chromabond SiOH, $150 \mathrm{ml} / 50 \mathrm{~g}$, Macherey-Nagel) previously conditioned with hexane. Elution was carried out using a gradient of $\mathrm{CH}_{2} \mathrm{Cl}_{2} /$ $\mathrm{MeOH}$ from 99:1 to 0:100 (v/v). The resulting fractions were collected, evaporated and stored at $4^{\circ} \mathrm{C}$ before use.

The most active fraction $(20 \mathrm{mg})$ was then laid on a preparative pre-coated TLC plate (SIL G-200, MachereyNagel) and eluted with $\mathrm{CH}_{2} \mathrm{Cl}_{2} / \mathrm{MeOH}$ 85:15 (v/v). After drying, part of the plate was revealed with sulphuric vanillin $(1 \mathrm{~g}$ of vanillin in $100 \mathrm{~mL}$ of $\mathrm{MeOH}$ and $1 \mathrm{~mL}$ of concentrated sulphuric acid). Each spot was then scratched, dissolved in $\mathrm{CH}_{2} \mathrm{Cl}_{2} / \mathrm{MeOH}$ 85:15 (v/v), centrifuged and the supernatants were evaporated and stored at $4^{\circ} \mathrm{C}$ before use.

The active spot was investigated on a HPLC system (Dionex) with a 600E pump and an ASI-100 autosampler injector and UV detection at $215 \mathrm{~nm}$. Separation was performed on an Econosil C18 (Alltech) column (10 mm ID $\times 250 \mathrm{~mm} \mathrm{1)} \mathrm{heated} \mathrm{at} 30^{\circ} \mathrm{C}$. A multi-step eluting gradient $\left(\mathrm{MeOH} / \mathrm{H}_{2} \mathrm{O}\right.$ 85:15 0-15 min, $\mathrm{MeOH} / \mathrm{H}_{2} \mathrm{O}$ 100:0 15-30 min, $\mathrm{MeOH} / \mathrm{H}_{2} \mathrm{O} 85: 15$ 30-40 min) was used at a flow rate of $3 \mathrm{~mL} \min ^{-1}$. The volume used for each injection was $500 \mu$ l. Each peak was collected, evaporated and stored at $4^{\circ} \mathrm{C}$ before use.

Identification of the active compound

Mass spectrometry experiments An Agilent Technologies 1100 Series vacuum degasser, LC pump and autosampler (Hewlett-Packard, Germany) were used to analyse the fraction isolated after $\mathrm{C}_{18}$ HPLC. Twenty microliters of sample solutions were applied onto an analytical $\mathrm{C}_{18}$ reversed-phase column (Hypersil ODS, $250 \times 4.6 \mathrm{~mm}$, particle size $5 \mu \mathrm{m})$. The elution procedure consisted of an isocratic profile of methanol-water $(15: 85, \mathrm{v} / \mathrm{v})$ for $5 \mathrm{~min}$, followed by a linear gradient from 85 to $100 \%$ methanol over $15 \mathrm{~min}$, and an isocratic profile with $100 \%$ methanol over $20 \mathrm{~min}$. The LC flow $\left(0.4 \mathrm{~mL} \mathrm{~min}^{-1}\right)$ was split (1/12) using a micro-splitter valve (Upchurch Scientific, USA). The post-column additive, a mixture of $5 \mathrm{mM}$ ammonium acetate and $0.05 \%$ trifluoroacetic acid (TFA) (Analysis grade, Carlo Erba) in methanol-water $(50: 50$, v/v), was added using a Cole-Parmer (USA) syringe pump and a 2.5-mL SGE syringe at a flow-rate $150 \mu \mathrm{L} \mathrm{h}{ }^{-1}$. The LCseparated compounds were detected by electrospray ionisation ion trap mass spectrometry (ESI-MS) using a Bruker Esquire-LC spectrometer (Bruker Daltonic, Germany) under positive-ion conditions. For each compound, two ions were formed: the $[\mathrm{M}+\mathrm{H}]^{+}$and the $[\mathrm{M}+\mathrm{Na}]^{+}$ions. The $[\mathrm{M}+\mathrm{H}]^{+}$ions were isolated for MS-MS fragmentation. The MS-MS chromatographic analysis is segmented for the isolation and fragmentation of the eluted $[\mathrm{M}+\mathrm{H}]^{+}$ ion. The electrospray used nitrogen as a nebulising gas (pressure set to 15 p.s.i.) and a drying gas (flow set to $7 \mathrm{~mL}$ $\min ^{-1}$ ). The drying temperature was $300^{\circ} \mathrm{C}$. The helium pressure in the ion trap was $6 \times 10^{-6}$ mbar. Full-scan mode detection was used with a scan range from $\mathrm{m} / \mathrm{z} 50$ to 700 . The software used was Bruker Esquire-LC NT version 6.08 and Agilent Technologies ChemStation May 1998.

NMR experiments NMR experiments were performed at $25^{\circ} \mathrm{C}$ in a Bruker Avance DRX 500 spectrometer equipped with an indirect $5 \mathrm{~mm}$ triple TBI $1 \mathrm{H} /\{\mathrm{BB}\} / 13 \mathrm{C}$ probehead using standard pulse sequences available in the Bruker software. The samples were dissolved in $700 \mu \mathrm{L}$ of $99.8 \%$ MeOD. 1D 1H spectra were recorded at $500.13 \mathrm{Mhz}$ with a $30^{\circ}$ pulse, a delay D1 of $2 \mathrm{~s}$ and 64 scans. Chemical shifts were expressed in ppm relative to TMS (Tetrametylsilane) as external standard. Double-quantum filtered ${ }^{1} \mathrm{H}-{ }^{1} \mathrm{H}$ correlated spectroscopy (DQF COSY), heteronuclear multiple quantum coherence (HMQC), heteronuclear multiple bond coherence $(\mathrm{HMBC})$ with a 60 -ms mixing time were performed according to standard pulse sequences to assign ${ }^{1} \mathrm{H}$ and ${ }^{13} \mathrm{C}$ resonances.

Gas chromatography experiments Active fraction was evaporated under nitrogen and methylated by contact with methanol/sulphuric acid $(98: 2, \mathrm{v} / \mathrm{v})$ in excess for one night at $50^{\circ} \mathrm{C}$. After cooling, $2 \mathrm{~mL}$ of pentane and $1 \mathrm{~mL}$ of water were added and vortexed. The upper organic phase was assayed using GC-MS on a Hewlett-Packard model 6890 series II gas chromatograph attached to an Agilent model 5973N selective quadripole mass detector. GC-MS was connected to a computer with Hewlett-Packard chemstation and the ionisation voltage used was $70 \mathrm{eV}$ at $250^{\circ} \mathrm{C}$. The temperature of injector and interface were maintained at 
$250^{\circ} \mathrm{C}$ and Helium was used as a carrier gas under constant flow $\left(1 \mathrm{~mL} \mathrm{~min}{ }^{-1}\right)$. Separation was realised on a CP-Sil 5 CB low bleed MS (Chrompack; $60 \mathrm{~m} \times 0.25 \mathrm{~mm}$ i.d., 0.25 $\mu \mathrm{m}$ film thickness). The oven temperature was programmed from 80 to $170^{\circ} \mathrm{C}$ at a rate of $30^{\circ} \mathrm{C} \mathrm{min}^{-1}$, then from 170 at $295^{\circ} \mathrm{C}$ with a rate of $3^{\circ} \mathrm{C} \mathrm{min}^{-1}$.

\section{Bioassays}

Antibacterial activities The marine bacterial strain was obtained from the Culture Collection of the IUT of Quimper (LUMAQ, UBO, France) and identified by the CIMB (Institut Pasteur, Paris, France) as Rhodobacteraceae bacterium R11 A. This bacterium was associated with immersed surfaces and isolated from decomposing seaweeds (Hellio et al. 2004). Antibacterial evaluation of the extracts and fractions was performed in 96-well plates as previously described in Bazes et al. (2006). Samples of cultures grown overnight $\left(2 \times 10^{8}\right.$ cells $\left.\mathrm{mL}^{-1}\right)$ were incubated with extracts and biocides (at the concentration of 25 , $50,100,200$ and $300 \mu \mathrm{g} \mathrm{mL}^{-1}$ ) for $48 \mathrm{~h}$ at $20^{\circ} \mathrm{C}$ (Maréchal et al. 2004). All inhibition assays were carried out in triplicate. Growth was monitored by measuring $\mathrm{OD}_{600}$ with a Packard Spectracount microplate spectrophotometer and the percentage of inhibition was calculated for each concentration:

$\%$ inhibition $=\left(O D_{c}-O D_{c}\right) / O D_{c} \times 100$

where $\mathrm{OD}_{\mathrm{c}}$ is the mean optical density of the bacterial controls and $\mathrm{OD}_{\mathrm{t}}$ is the mean optical density of the test samples. Control testing with the solvents and $\mathrm{N}$-decane $1 \%$ was performed for every assay and showed no inhibition of the microbial growth. Seawater was used as a negative control.

Inhibition of phytoplankton growth Cylindrotheca closterium (Diatomophyceae, AC515) was obtained from the Culture Collection of Algae of the University of Caen (France). It was used as a common fouling species (Jackson 1991; Hellio et al. 2004). Screening for bioactivity was performed as described by Sawant et al. (1995) and modified in Bazes et al. (2006). The effect of algal extracts and fractions (at the concentration of 25, 50, 100, 200 and $300 \mu \mathrm{g} \mathrm{mL}^{-1}$ ) was assessed after $72 \mathrm{~h}$ by estimating the chlorophyll-a (Aminot 1983). All the screening experiments were carried out in triplicate. The percentage of growth inhibition was calculated:

$\%$ inhibition $=\left(\right.$ Chla $\left._{\mathrm{c}}-\mathrm{Chla}_{\mathrm{t}}\right) / \mathrm{Chla}_{\mathrm{c}} \times 100$

where $\mathrm{Chla}_{\mathrm{c}}$ is the mean concentration of chlorophyll-a of the algal controls and $\mathrm{Chla}_{\mathrm{t}}$ is the mean concentration of chlorophyll-a of the test samples. Control tests with the solvents and $N$-decane $1 \%$ were performed for every assay and showed no inhibition of the microalgal growth. Seawater was used as a negative control.

Inhibition of germination of Ulva spores Ulva lactuca (Ulvales, Chlorophyta) samples were collected in July and September 2004 at Locmariaquer, South Brittany, France $\left(47^{\circ} 33^{\prime} \mathrm{N}, 02^{\circ} 56^{\prime} \mathrm{W}\right)$. Spores were obtained using the osmotic method (Fletcher 1989). Tests of algal extracts and fractions on spores were performed as described by Hattori and Shizuri (1996) and Bazes et al. (2006), by determining the percentage of inhibition of germination of spores $\left(600 \mathrm{~mL}^{-1}\right)$ in plastic Petri dishes after incubation for 5 days at $20^{\circ} \mathrm{C}$ under $24 \mathrm{~h}$ light. All the screening experiments were carried out in triplicate. The percentage of growth inhibition was calculated:

$\%$ inhibition $=\left(\mathrm{gs}_{\mathrm{c}}-\mathrm{gs}_{\mathrm{t}}\right) / \mathrm{gs}_{\mathrm{c}} \times 100$

where $\mathrm{gs}_{\mathrm{c}}$ is the mean number of germinated spores for the controls and $\mathrm{gs}_{\mathrm{t}}$ is the mean number of germinated spores for the test samples. Seawater was used as a negative control.

\section{Toxicity}

Cytotoxicity evaluation by cell viability was performed by the neutral red dye method (McLaren et al. 1983) on 3 T3 as described in Bazes et al. (2006). Cellular suspensions (3,5× $10^{5} 3 \mathrm{~T} 3$ cells $\mathrm{mL}^{-1}$ purchased from Eurobio) were incubated with various concentrations of algae extracts and biocides (10-300 $\mu \mathrm{g} \mathrm{mL}^{-1}, 4$ wells per concentration) in 96-well plates $\left(72 \mathrm{~h}, 37^{\circ} \mathrm{C}, 5 \% \mathrm{CO}_{2}\right)$ in Eagle's MEM $10 \%$ FCS. The same experiment has been conducted with Vero cells. All the cytotoxicity experiments were carried out in triplicate. The cytotoxic concentration $\left(\mathrm{CC}_{50}\right)$ was expressed by a percentage of destruction:

$\%$ destruction $=\left(O D_{c}-O D_{t}\right) / O D_{c} \times 100$

where $\mathrm{OD}_{\mathrm{c}}$ is the mean optical density of the cell controls at $540 \mathrm{~nm}$ and $\mathrm{OD}_{\mathrm{t}}$ is the mean optical density of the test samples at $540 \mathrm{~nm}$.

\section{Statistical analysis}

Percentage of growth inhibition was calculated for each microfouling organisms as described previously. The $50 \%$ effective concentrations $\left(\mathrm{EC}_{50}\right)$ and cytotoxic concentrations $\left(\mathrm{CC}_{50}\right)$ were estimated by regression analysis with Prism software, Version 4 (GraphPad Software). All calculations were based on measured concentrations of extracts, and $\mathrm{CC}_{50}$ and $\mathrm{EC}_{50}$ were given when it was in the range of concentrations. 


\section{Results}

In situ testing

Results of the in situ tests are shown on Fig. 1. No barnacles or mussels were observed on the test rack. The paint including only copper is less efficient than the paints including the crude extract. When copper and crude extract are included together in the paint, there is much less fouling than on the other coatings: $37 \%$ of the plate painted with crude extract of Sargassum muticum and copper are covered with young thalli of Ulva sp., while $92 \%$ of the plate painted only with $S$. muticum extract, and $100 \%$ of the plate painted only with copper, are covered with different green algae (mostly from the genus Ulva), and red algae (mostly from the genus Polysiphonia). Welldeveloped thalli of Ulva sp. were observed on those last two plates.

\section{Identification of the active compound}

Solid phase extraction of the crude extract (A) allowed for the isolation of an active fraction in the $\mathrm{CH}_{2} \mathrm{Cl}_{2} / \mathrm{MeOH}$ $70: 30$ part (B) $(91.5 \mathrm{mg})$. The preparative TLC of that sample gave 8 fractions. Fraction no.5 (C) $(22.8 \mathrm{mg})$ was active and it was analysed by HPLC on a $\mathrm{C} 18$ column using a $\mathrm{MeOH} / \mathrm{H}_{2} \mathrm{O}$ gradient as the eluent. After HPLC, ten fractions were isolated. The eighth one (D) $(2.7 \mathrm{mg}$ of a pale green oil) was inhibitory to the growth of the three organisms tested. This last fraction was isolated in large quantities for the identification of bioactive molecules.

MS on the D fraction showed a peak corresponding to two ions. The $\mathrm{m} / \mathrm{z} 413.4$ ion was found in a majority while the $\mathrm{m} / \mathrm{z} 391.4$ ion was in a minority, corresponding to the $[\mathrm{M}+\mathrm{H}]+$ and $[\mathrm{M}+\mathrm{Na}]+$ ions of the octyl phthalate. MS-MS detection was then used for identification. The $\mathrm{m} / \mathrm{z} 413.4$ ion gave no signal in those conditions, while the $\mathrm{m} / \mathrm{z} 391.4$ ion produced a m/z 149 fragment, typically representative of phthalates.

NMR on the $\mathrm{D}$ fraction showed that protons from terminal methyl groups show one badly defined triplet at $0.88 \mathrm{ppm}$ (mainly from 16:0 acyl chains). A multiplet at $1.2 \mathrm{ppm}$ is assigned to the methylene protons. The multiplet at $2.36 \mathrm{ppm}$ corresponds to the $\mathrm{C}_{\mathrm{a}} \mathrm{H}_{2}$ group and the signal at $1.58 \mathrm{ppm}$ to the $\mathrm{C}_{\mathrm{b}} \mathrm{H}_{2}$ group (where $\mathrm{a}$ and $\mathrm{b}$ positions are relative to the carbonyl group). Those signals reveal that this fraction is mostly constituted of lipid chains. The integration and the lack of unsaturated signals at about $5.5 \mathrm{ppm}$ confirm that most of the lipid chains are 16:0 (palmitic acid). The HMQC spectrum allowed the specific assignment of ${ }^{1} \mathrm{~J}$ carbons and HMBC sequencing determined the shift of the carbonyl group. To confirm the results obtained by NMR and to determine the abundance of fatty acids, GC-MS analyses were performed on every sample.

The fatty acid content of every sample is shown in Table 2. The crude extract contains $99 \%$ fatty acids and $1 \%$ contaminant. This table highlights that the different steps used during the purification process led to the loss of most of the fatty acids present in the crude extract, the only main one remaining in the $\mathrm{D}$ fraction. The analysis of fraction $\mathrm{D}$ confirmed the results obtained with NMR. As it was not possible to separate the two main compounds from the D fraction, palmitic acid and dioctyl phthalate were purchased from Sigma and were investigated separately for their antifouling activity in order to determine the role of each in the activity of the fraction

\section{Antifouling activities of the different isolated fractions}

The antifouling activities of the crude extract, the HPLC purified fraction, the palmitic acid and dioctyl phthalate
Fig. 1 A test rack, which was exposed to a marine environment for 2 months, showing less fouling on the samples containing extract and copper than on the samples only containing extract or copper. 1: Paint with crude extract from Sargassum muticum without copper. 2: Paint with crude extract from Sargassum muticum and copper. 3: Paint only with copper

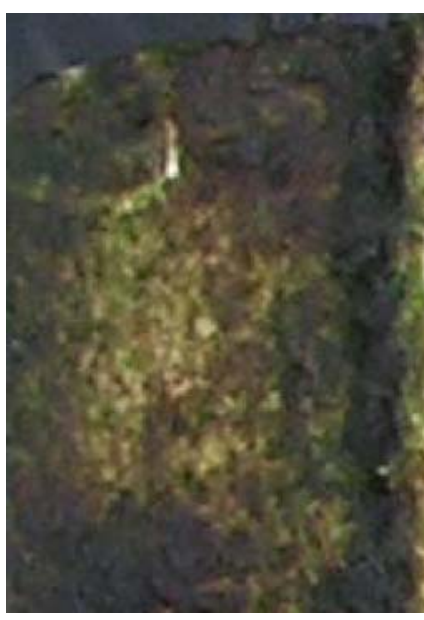

1

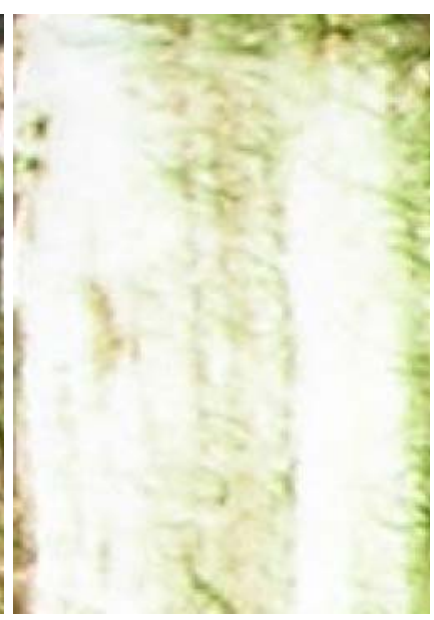

2

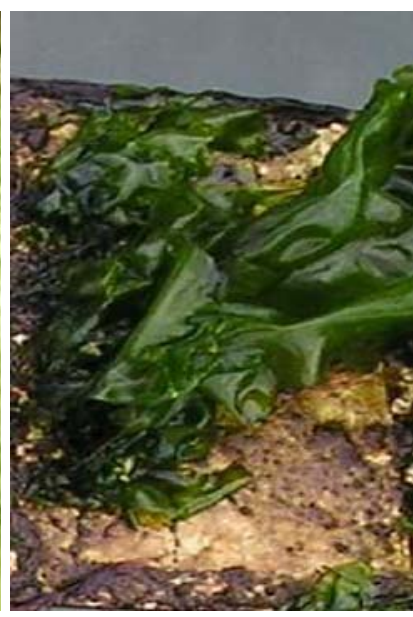

3 
Table 2 GC-MS analysis of the methylated isolated fraction

\begin{tabular}{|c|c|c|c|}
\hline Crude extract (A) & $\begin{array}{l}\text { Solid phase } \\
\text { extraction (B) }\end{array}$ & TLC (C) & HPLC (D) \\
\hline $16: 0(31.5 \%)$ & $16: 0(62.1 \%)$ & $16: 0(49.8 \%)$ & $16: 0(71 \%)$ \\
\hline $14: 0(3.14 \%)$ & $14: 0(6.2 \%)$ & $14: 0(7.1 \%)$ & $14: 0(1 \%)$ \\
\hline $15: 0(0.36 \%)$ & $15: 0(0.8 \%)$ & $18: 0(8.1 \%)$ & $18: 0(7 \%)$ \\
\hline $16: 1 \omega 7(7.60 \%)$ & $16: 1 \omega 7(1.3 \%)$ & $\begin{array}{l}\text { Dioctyl } \\
\text { phthalate } \\
(6.3 \%)\end{array}$ & $22: 0(3 \%)$ \\
\hline $16: 1 \omega 9(0.91 \%)$ & $16: 1 \omega 9(1.5 \%)$ & & $\begin{array}{l}\text { Dioctyl } \\
\text { phthalate } \\
(16 \%)\end{array}$ \\
\hline $18: 4 \omega 3(2.28 \%)$ & $18: 1 \omega 9(3.9 \%)$ & & \\
\hline $18: 2 \omega 6(5.39 \%)$ & $18: 0(1.8 \%)$ & & \\
\hline $18: 1 \omega 9(15.68 \%)$ & $20: 1 \omega 7(0.9 \%)$ & & \\
\hline $18: 1 \omega 7(1.57 \%)$ & $\begin{array}{l}\text { Dioctyl } \\
\text { phthalate } \\
(4 \%)\end{array}$ & & \\
\hline \multicolumn{4}{|l|}{ 18:0 (0.70\%) } \\
\hline \multicolumn{4}{|l|}{$20: 4 \omega 6(9.74 \%)$} \\
\hline \multicolumn{4}{|l|}{$20: 5 \omega 3(5.66 \%)$} \\
\hline \multicolumn{4}{|l|}{$20: 3 \omega 6(0.68 \%)$} \\
\hline \multicolumn{4}{|l|}{$20: 2 \omega 6(2.14 \%)$} \\
\hline \multicolumn{4}{|l|}{$20: 1 \omega 9(2.29 \%)$} \\
\hline \multicolumn{4}{|l|}{$22: 1 \omega 7(1.67 \%)$} \\
\hline \multicolumn{4}{|l|}{ Dioctyl } \\
\hline \multicolumn{4}{|l|}{ phthalate } \\
\hline$(0.95 \%)$ & & & \\
\hline
\end{tabular}

Dioctyl phthalate $=1,2$ benzenedicarboxylic acid, bis(2-ethylhexyl)ester

(Sigma) and commercial biocides were evaluated and are presented in Table 3. The remaining active fraction after the HPLC step (D) contains at least $70 \%$ palmitic acid and shows a better activity on every fouling organism tested than the four chemical biocides. Moreover, this fraction showed no toxicity on 3T3 cells. Palmitic acid purchased from Sigma was also tested for its antifouling activities and showed good antibacterial activity against Rhodobacteraceae bacterium R11A with an $\mathrm{EC}_{50}$ at $44 \mu \mathrm{g} \mathrm{mL}^{-1}$. Besides this antibacterial activity, palmitic acid also inhibits the development of a microalgal strain $(C$. closterium) at $45.5 \mu \mathrm{g} \mathrm{mL}^{-1}$ and the germination of spores from $U$. lactuca at $3 \mu \mathrm{g} \mathrm{mL}^{-1}$. Myristic (14:0) or stearic (18:0) acids were also tested on fouling organisms and none of them showed antifouling activity (data not shown).

Those results also show that palmitic acid has a better antibacterial activity than dioctyl phthalate while the dioctyl phthalate is inactive at concentrations up to $300 \mu \mathrm{g} \mathrm{mL}^{-1}$. However, the comparison of the activity of those two products on $C$. closterium shows that the dioctyl phthalate is more efficient than the palmitic acid with an $\mathrm{EC}_{50}$ lower than $25 \mu \mathrm{g} \mathrm{mL}^{-1}$. This $\mathrm{EC}_{50}$ is the same as for the crude extract. This suggests a synergetic effect between the dioctyl phthalate and the palmitic acid on the growth of C. closterium.

The biocides tested here showed a low antibacterial activity. Diuron and Dichlofluanid showed an inhibition of Rhodobacteraceae bacterium $R 11 A$ at less than $200 \mu \mathrm{g}$ $\mathrm{mL}^{-1}$, while Tolylfluanid showed no bacterial inhibition under $300 \mu \mathrm{g} \mathrm{mL}^{-1}$. Conversely, they all showed a good microalgal inhibition under $25 \mu \mathrm{g} \mathrm{mL}{ }^{-1}$. Irgarol, Tolylfluanid and dichlofluanid showed less inhibition of the germination of the spores than the extracts and purified fractions, while Diuron was active at $25 \mu \mathrm{g} \mathrm{mL}^{-1}$. The four biocides tested here showed high toxicity against 3T3 cells with a $\mathrm{CC}_{50}$ under $32 \mu \mathrm{g} \mathrm{mL}^{-1}$, while no cytotoxicity was observed at concentration lower than $300 \mu \mathrm{g} \mathrm{mL}^{-1}$ for the crude extract and purified fractions.

\section{Discussion}

In 2000, a study on the antifouling activity of extracts from 30 marine algae has been conduced (Hellio 2000). Statistical analysis of this study allowed the isolation promising potential antifouling of extracts from the brown seaweed Sargassum muticum. This study was confirmed and completed by the work of Hellio et al. (2004), while the study by Bazes (2006) showed that the most efficient

Table 3 Antifouling activity $\left(\mathrm{EC}_{50}\right.$ in $\left.\mu \mathrm{g} \mathrm{mL}^{-1}\right)$ and toxicity $\left(\mathrm{CC}_{50}\right.$ in $\mu \mathrm{g} \mathrm{mL}^{-1}$ ) of every most active fraction of the purification process and of palmitic acid and dioctyl phthalate

\begin{tabular}{|c|c|c|c|c|}
\hline Fraction & $\begin{array}{l}\text { Rhodobacteraceae } \\
\text { bacterium } R 11 \mathrm{~A}\end{array}$ & $\begin{array}{l}\text { C. } \\
\text { closterium }\end{array}$ & $\begin{array}{l}\text { Germination } \\
\text { of Ulva } \\
\text { lactuca }\end{array}$ & $\begin{array}{l}\mathrm{CC}_{50} \\
\text { on } \\
3 \mathrm{~T} 3 \\
\text { cells }\end{array}$ \\
\hline $\begin{array}{l}\text { Crude } \\
\text { extract (A) }\end{array}$ & 206.0 & $<25.0$ & $<25.0$ & $>300.0$ \\
\hline $\begin{array}{l}\text { SPE } \\
\text { fraction (B) }\end{array}$ & 150.0 & $<25.0$ & $<25.0$ & $>300.0$ \\
\hline $\begin{array}{l}\text { TLC } \\
\text { fraction (C) }\end{array}$ & 100.0 & $<25.0$ & $<25.0$ & $>300.0$ \\
\hline $\begin{array}{l}\text { Purified } \\
\text { fraction (D) }\end{array}$ & 50.0 & $<25.0$ & 18.0 & $>300.0$ \\
\hline $\begin{array}{l}\text { Dioctyl } \\
\text { phthalate } \\
\text { (Sigma) }\end{array}$ & $>300.0$ & $<25.0$ & $>300.0$ & $>300.0$ \\
\hline $\begin{array}{l}\text { Palmitic acid } \\
\text { (Sigma) }\end{array}$ & 44.0 & 45.5 & $<3.0$ & $>300.0$ \\
\hline Diuron & 80.7 & $<25.0$ & 25.0 & 32.0 \\
\hline Irgarol & 180.0 & $<25.0$ & 69.0 & 10.0 \\
\hline Tolyfluanide & $>300.0$ & $<25.0$ & 64.0 & 12.0 \\
\hline Dichlofluanide & 150.6 & $<25.0$ & 71.0 & 18.0 \\
\hline
\end{tabular}

All assays were carried out in triplicate. 
extract was produced from S. muticum harvested in March. The chemical composition of Sargassum has been studied extensively, but the present investigation was undertaken because there is no report regarding antifouling activity of purified compounds derived from S. muticum.

Palmitic acid is a common fatty acid in brown algae and, in the genus Sargassum, it can represent $20-40 \%$ of the total fatty acids (Vaskovsky et al. 1996; Li et al. 2002; Hossain et al. 2003; Kornprobst 2005). In S. muticum, it was shown to constitute $21.5 \%$ of the total fatty acids (Vaskovsky et al. 1996). Fatty acids can be produced from triglycerides by action of lipases and have to be included in chemical ecology studies (Noguchi et al. 1979). The fats and fatty acids from marine organisms can play an important role due to the wide diversity of their biological characteristics and their oxidative enzymes leading to the formation of many other bioactive secondary metabolites (Ganti et al. 2006). Indeed, some fatty acids have shown antibacterial or bacteriostatic activities (C8-C12), while C4$\mathrm{C} 12$ fatty acids have antifungal activities and C7-C12 fatty acids inhibit the growth of Chlorella sp. (Noguchi et al. 1979). Active antibacterial extracts from different brown algae (Alaria marginata, Desmarestia ligulata, Dictyota pfaffii, Egregia menziesii, Eisenia arborea, Fucus distichus, Laminaria saccharina, Macrocystis integrifolia, Nereocystis luetkeana and Pleurophycus gardneri) have been found to be made up of saturated and unsaturated fatty acids, with a predominance of myristic, palmitic, oleic, arachidonic and eicosapentaenoic acids (Rosell and Srivastava 1987; Barbosa et al. 2007). A mixture of fatty acids from a lipophilic fraction from Skeletonema costatum has also shown an interesting level of inhibition on the growth of Vibrio anguillarum and other pathogens associated with the aquaculture industry (Naviner et al. 1999). Hexadecyl palmitate isolated from the alcyonacean soft coral Sinularia polydactyla was also shown to be active against Vibrio harveyi (Risk et al. 1997). The sulphoglycerolipid 1-Opalmitoyl-3- $O\left(6^{\prime}\right.$-sulpho- $\alpha$-quinovopyranosyl)-glycerol isolated from the methanolic extract of the brown seaweed Sargassum wightii is active against Xanthomonas oryzae. This compound is mainly formed from palmitic acid (Arunkumar et al. 2005). A method developed to control biofouling using polyglycol fatty ester has shown that pure palmitic acid may be used to inhibit bacteria from adhering to a submergible surface (Glover et al. 1997). Those studies confirm the biological activity of palmitic acid observed in our work. The type and amount of free fatty acids can then have a role in the overall defence against microbial colonisation (Benkendorff et al. 2005), but we have shown here that a fatty acid can have an effect on other microfouling organisms.

However, we have also highlighted the presence of the 1,2 benzenedicarboxylic acid, bis(2-ethylhexyl) ester (or dioctyl phthalate; di-(2-ethylhexyl)-phthalate or DEHP), which is a plasticiser and constitutes $16 \%$ of the active fraction of $S$. muticum. Pthalate esters are likely contaminants from plastics in the laboratory encountered during the extraction or isolation process and are commonly found during natural products isolation. However, phthalate ester may also come from the coastal environment and/or reflect a phenomenon of bioaccumulation (Peakall 1975). Phthalate esters have been found in soils, plants, and aquatic organisms (Morris 1970; Peakall 1975; Melancon and Lech 1976; Noguchi et al. 1979; Wofford et al. 1981; Stales et al. 1997; Chen 2004; Mackintosh et al. 2004; Cho et al. 2005). Because of their lipophilicity, they can be potentially bioaccumulated by organisms (Mackintosh et al. 2004). The biosynthesis of di-(2-ethylhexyl)-phthalate has been studied by Chen (2004), who has shown that the red alga Bangia atropurpurea was synthesising this compound de novo. In algae, di-(2-ethylhexyl)-phthalate has been isolated from Ceramium rubrum, but the origin of this phthalate had not been elucidated (Noguchi et al. 1979). Dioctyl phthalate has also been isolated from the brown algae $S$. wightii (Sastry and Rao 1995), Ishige okamurae (Cho et al. 2005) and S. confusum (Ganti et al. 2006). The dioctyl phthalate isolated from $S$. wightii has shown antibacterial activity against Staphylococcus aureus, Proteus vulgaris, E. coli, Salmonella typhi, S. paratyphi A, S. typhiridium and Pseudomonas aeruginosa (Sastry and Rao 1995). This phthalate was isolated in a lipid fraction, not unlike in our study. The other extracts of algae studied by those authors and harvested at the same place did not show any antibacterial activity (Sastry and Rao 1994), which suggested that the antibacterial compound of interest did not come from the environment. Di-n-octylphthalate (DNOP) has been isolated from Ishige okamurae and tested against the mussel Mytilus edulis and the green alga $U$. prolifera (Cho et al. 2005). Total repulsion of the mussel feet was induced by $0.3 \mathrm{mM}$ of DNOP, and $1 \mathrm{mM}$ of DNOP showed a reduction of $7.5 \%$ in spore fixation compared to a seawater control. Dioctyl phthalate also has been isolated from $S$. confusum and tested on spore attachment of $U$. pertusa (Ganti et al. 2006). Concentrations of 1 to $100 \mu \mathrm{g}$ $\mathrm{mL}^{-1}$ inhibited $53-86 \%$ of spore attachment.

The role of the phthalate ester in the active fraction of $S$. muticum does not seem to be important, except against the growth of the phytoplanktonic strain, but it would be interesting to determine its origin.

In conclusion, fatty acid esters can play an important role in the defence and protection against bacterial development, providing they can be present in sufficient quantities on the considered surface (Benkendorff et al. 2005). The relevant literature leads us to believe that palmitic acid could be responsible for the antifouling activity observed in the active fraction isolated from S. muticum. Two patents 
(Glover et al. 1997; Risk et al. 1997) already show the potential of pure palmitic acid as an antibacterial compound which could be used in wood protection (Risk et al. 1997), or of one of its derivates, hexadecyl palmitate, which could inhibit bacterial colonisation of a submersed surface (Glover et al. 1997). The tests conducted with commercial palmitic acid on representative organisms of primary colonisation show good activity at low concentrations. Moreover, no toxicity was observed on the cell models used. This compound has potential for the development of an environmentally friendly antifouling product. Furthermore, it can be easily purchased, so there is no need to carry out expensive and time-consuming extractions from S. muticum. New assays in paints for commercial palmitic acid and D fraction are currently under development to compare their activity in vivo.

\section{References}

Abarzua S, Jakubowski S (1995) Biotechnological investigation for the prevention of biofouling: I. Biological and biochemical principles for the prevention of biofouling. Mar Ecol Prog Ser 123:301-312, doi:10.3354/meps123301

Aminot A. (1983b) Dosage de la chlorophylle et des phéopigments par spectrophotomètrie In: Manuel des analyses physicochimiques en milieu marin (Aminot A. and Chaussepied), pp. 177-192. CNEXO, BNDO/ Documentation, Brest

Arunkumar K, Narayanan Selvapalam N, Rengasamy R (2005) The antibacterial compound sulphoglycerolipid 1-0 palmitoyl-3-0(6'sulpho-alpha-quinovopyranosyl)-glycerol from Sargassum wightii Greville (Phaeophyceae). Bot Mar 48:441-445, doi:10.1515/BOT.2005.058

Bakus GJ, Targett NM, Schulte B (1986) Chemical ecology of marine organisms: an overview. J Chem Ecol 12:951-987, doi:10.1007/ BF01638991

Banaimoon SA (1992) Fatty acids in marine macroalgae from southern Yemen (Hadarmout) including occurrence of eicosatetraenoic (20:4) and eicosapentaenoic (20:5) acids. Bot Mar $35: 165-168$

Barbosa JP, Fleury BG, da Gama BAP, Teixeira VL, Pereira RC (2007) Natural products as antifoulants in the Brazilian brown alga Dictyota pfaffii (Phaeophyta, Dictyotales). Biochem Syst Ecol 35:549-553, doi:10.1016/j.bse.2007.01.010

Bazes A (2006) Recherche et valorisation de principes actifs antifouling isolés à partir de trois macroalgues. Thèse de doctorat, Université de Bretagne-Sud

Bazes A, Silkina A, Defer D, Bernède-Bauduin C, Quéméner E, Braud J-P, Bourgougnon N (2006) Active substances from Ceramium botryocarpum used as antifouling products in aquaculture. Aquaculture 258:664-674, doi:10.1016/j.aquaculture.2006. 04.017

Benkendorff K, Davis AR, Rogers CN, Bremner JB (2005) Free fatty acids and sterols in the benthic spawn of aquatic molluscs, and their associated antimicrobial properties. J Exp Mar Biol Ecol 316:29-44, doi:10.1016/j.jembe.2004.10.001

Chambers LD, Stokes KR, Walsh FC, Wood RJK (2006) Modern approaches to marine antifouling coatings. Surf Coat Tech 201:3642-3652, doi:10.1016/j.surfcoat.2006.08.129

Chen CY (2004) Biosynthesis of di-(2-ethylhexyl) phthalate (DEHP) and di-n-butyl phthalate (DBP) from red alga Bangia atropur- purea. Water Res 38:1014-1018, doi:10.1016/j.watres.2003. 11.029

Cho JY, Choi JS, Kang SE, Kim JK, Shin HW, Hong YK (2005) Isolation of antifouling active pyroglutamic acid, triethyl citrate and di-n-octylphthalate from the brown seaweed Ishige okamurae. J Appl Phycol 17:431-435, doi:10.1007/s10811-0050460-y

Critchley AT, Farnham WF, Yoshida T, Norton TA (1990) A bibliography of the invasive alga Sargassum muticum (Yendo) Fensholt (Fucales, Sargassaceae). Bot Mar 33:551-562

Davis AR, Targett NM, McConnel OJ, Young CM (1989) Epibiosis of marine algae and benthic invertebrates: natural products chemistry and other mechanisms inhibiting settlement and overgrowth. In: Scheuer PJ (ed) Bioorganic marine chemistry. 3. Springer, Berlin, pp 85-114

Fletcher RL (1989) A bioassay technique using the marine fouling green alga Enteromorpha. Int Biodeterior 25:407-422, doi:10.1016/0265-3036(89)90067-5

Fusetani N (2004) Biofouling and antifouling. Nat Prod Rep 21:94104, doi:10.1039/b302231p

Ganti VS, Kim KH, Bhattarai HD, Shin HW (2006) Isolation and characterisation of some antifouling agents from the brown alga Sargassum confusum. J Asian Nat Prod Res 8:309-315, doi:10.1080/10286020500034980

Glover DE, Whittemore MS, Bryant SD (1997) Methods and compositions for controlling biofouling using polyglycol fatty acid esters. International Patent Application WO 97/11912

Harlin M (1996) Allelochemistry in marine algae. Crit Rev Plant Sci 5:237-249

Harvey HR, Kennicutt MC (1992) Selective alteration of Sargassum lipids in anoxic sediments of the Orca basin. Org Geochem 18:181-187, doi:10.1016/0146-6380(92)90128-K

Hattori T, Shizuri Y (1996) A screening method for antifouling substances using spores of the fouling macroalga Ulva conglobata Kjellman. Biofouling 8:147-160

Hay ME (1996) Marine chemical ecology: what's known and what's next? J Exp Mar Biol Ecol 200:103-134, doi:10.1016/S00220981(96)02659-7

Hay ME, Fenical W (1988) Marine plant-herbivore interactions: The ecology of chemical defense. Annu Rev Ecol Syst 19:111-145, doi:10.1146/annurev.es.19.110188.000551

Hellio C (2000) Recherche de nouvelles substances à activité antifouling à partir de macroalgues du Littoral Breton. Thèse de Doctorat, Université de La Rochelle

Hellio C, De La Broise D, Dufossé L, Le Gal Y, Bourgougnon N (2001) Inhibition of marine bacteria by extracts of macroalgae: potential use for environmentally friendly antifouling paints. Mar Environ Res 52:231-247, doi:10.1016/S0141-1136(01)00092-7

Hellio C, Marechal J-P, Véron B, Bremer AG, Clare AS, Le Gal Y (2004) Seasonal variation of antifouling activities of marine algae from the Brittany coast (France). Mar Biotechnol 6:67-82, doi:10.1007/s10126-003-0020-x

Hossain Z, Kurihara H, Takahashi K (2003) Biochemical composition and lipid compositional properties of the brown alga Sargassum horneri. Pak J Biol Sci 6(17):1497-1500

Jackson SM (1991) Microalgae: Their status as fouling organisms. OEbalia (Taranto) 17(1):295-303

Kornprobst J-M (2005) Substances naturelles d'origine marine, Vol 1: Généralités, micro-organismes, algues. Tec \& Doc, Paris

Kubo I, Himejima M, Tsujmoto K, Muroi H, Ichikawa N (1992) Antibacterial activity of crinitol and its potentiation. J Nat Prod 55:780-785, doi:10.1021/np50084a012

Lambert SJ, Thomas KV, Davy AJ (2006) Assessment of the risk posed by the antifouling booster biocides Irgarol 1051 and diuron to freshwater macrophytes. Chemosphere 63:734-743, doi:10.1016/j.chemosphere.2005.08.023 
Li X, Fan X, Han L, Lou Q (2002) Fatty acids of some algae from the Bohai Sea. Phytochem 59:157-161, doi:10.1016/S0031-9422(01)00437-X

Mackintosh CE, Maldonado J, Hongwu J, Hoover N, Chong A, Ikonomou MG, Gobas FAPC (2004) Distribution of phthalate esters in a marine aquatic food web: comparison to polychlorinated biphenyls. Environ Sci Technol 38:2011-2020, doi:10.1021/es034745r

Maréchal JP, Culioli G, Hellio C, Thomas-Guyon H, Callow. ME, Clare AS, Ortalo-Magné A (2004) Seasonal variations in antifouling activity of crude extracts of the brown alga Bifurcaria bifurcata against cyprids of Balanus amphitrite and the marine bacteria Cobetia marina and Pseudoalteromonas haloplanktis. J Exp Mar Biol Ecol 313:47-62

McLaren C, Ellis MN, Hunter GA (1983) A colorimetric assay or the measurement of the sensitivity of Herpes simplex viruses to antiviral agents. Antiviral Res 3:223-234, doi:10.1016/01663542(83)90001-3

Melancon MJ Jr, Lech JJ (1976) Distribution and biliary excretion products of di-2-ethylhexyl phthalate in rainbow trout. Drug Metab Dispos 4:112-118

Morris RJ (1970) Phthalic acid in deep sea jellyfish Atolla. Nature 227:1264, doi: $10.1038 / 2271264 \mathrm{a} 0$

Naviner M, Bergé J-P, Durand P, Le Bris H (1999) Antibacterial activity of the marine diatom Skeletonema costatum against aquacultural pathogens. Aquaculture 174:15-24, doi:10.1016/ S0044-8486(98)00513-4

Noguchi T, Ikawa M, Uebel JJ, Andersen KK (1979) Lipid constituents of the red algae Ceramium rubrum. A search for antimicrobial and chemical defense substances. In: Hoppa HA, Levring T, Tanaka Y (eds) Marine algae in pharmaceutical science. de Gruyter, NY, pp 711-718

Peakall DB (1975) Phthalate esters: Occurence and biological effects. Residue Rev 54:1-41

Plouguerne E, Le Lann K, Connan S, Jechoux G, Deslandes E, StigerPouvreau V (2006) Spatial and seasonal variation in density, reproductive status, length and phenolic content of the invasive brown macroalga Sargassum muticum (Yendo) Fensholt along the coast of Western Brittany (France). Aquat Bot 85:337-346, doi:10.1016/j.aquabot.2006.06.011

Risk M, Harrison P, Lewis J (1997) Wood preserving composition. Patent Application WO 97/34747
Rosell K, Srivastava L (1987) Fatty acids as antimicrobial substances in brown algae. Hydrobiologia 151-152:471-475, doi:10.1007/ BF00046169

Sastry VMVS, Rao GRK (1994) Antibacterial substances from marine algae: successive extraction using benzene, chloroform and methanol. Bot Mar 37:357-360

Sastry VMVS, Rao GRK (1995) Dioctyl phthalate and antibacterial compound from marine brown alga Sargassum wightii. J Appl Phycol 7:185-186, doi:10.1007/BF00693066

Sawant SS, Sonak S, Garg A (1995) Growth inhibition of fouling bacteria and diatoms by extract of terrestrial plant, Derris scandens (Dicotyledonae:Leguminocae). Indian J Mar Sci 24:229-230

Sieburth JM, Conover JT (1965) Sargassum tannin, an anti-biotic which retards fouling. Nature 208:52-53, doi:10.1038/ 208052a0

Stales CA, Peterson DR, Parkerton TF, Adams WJ (1997) The environmental fate of phthalate esters: a literature review. Chemosphere 35:667-749, doi:10.1016/S0045-6535(97)00195-1

Steinberg PD (1992) Geographical variation in the interaction between marine herbivores and brown algal secondary metabolites. In: Paul VJ (ed) Ecological roles of marine natural products. Cornell University Press, Ithaca, pp 51-92

Steinberg PD, de Nys R, Kjelleberg S (1998) Chemical inhibition of epibiota by Australian seaweeds. Biofouling 12:227-244

Vaskovsky VE, Khotimchenko SV, Xia B, Hefang L (1996) Polar lipids and fatty acids of some marine macrophytes from the Yellow Sea. Phytochemistry 42:1347-1356, doi:10.1016/00319422(96)00117-3

Wahl M (1989) Marine epibiosis: I. Fouling and antifouling: some basic aspects. Mar Ecol Prog Ser 58:175-189, doi:10.3354/ meps058175

Wofford HW, Wilsey CD, Neff GS et al (1981) Bioaccumulation and metabolism of phthalate esters by oysters, brown shrimp and sheepshead. Ecotoxicol Environ Saf 5:202-210, doi:10.1016/ 0147-6513(81)90035-X

Yebra DM, Kiil S, Dam-Johansen K (2004) Antifouling technologypast, present and future step towards efficient and environmentally friendly antifouling coatings. Prog Org Coat 50:75-104, doi:10.1016/j.porgcoat.2003.06.001 